\title{
Temporality in British young women's magazines: food, cooking and weight loss
}

\author{
Rosemary J Spencer ${ }^{1}$, Jean M Russell ${ }^{2}$ and Margo E Barker ${ }^{1, *}$ \\ 'Human Nutrition Unit, Department of Oncology, University of Sheffield, The Medical School, Beech Hill Road, \\ Sheffield S10 2RX, UK: ${ }^{2}$ Corporate Information and Computing Service, University of Sheffield, Sheffield, UK
}

Submitted 12 June 2012: Final revision received 13 August 2013: Accepted 14 August 2013: First published online 14 October 2013

\begin{abstract}
Objective: The present study examines seasonal and temporal patterns in foodrelated content of two UK magazines for young women focusing on food types, cooking and weight loss.

Design: Content analysis of magazines from three time blocks between 1999 and 2011.

Setting: Desk-based study.

Subjects: Ninety-seven magazines yielding 590 advertisements and 148 articles. Results: Cluster analysis of type of food advertising produced three clusters of magazines, which reflected recognised food behaviours of young women: vegetarianism, convenience eating and weight control. The first cluster of magazines was associated with Christmas and Millennium time periods, with advertising of alcohol, coffee, cheese, vegetarian meat substitutes and weightloss pills. Recipes were prominent in article content and tended to be for cakes/ desserts, luxury meals and party food. The second cluster was associated with summer months and 2010 issues. There was little advertising for conventional foods in cluster 2, but strong representation of diet plans and foods for weight loss. Weight-loss messages in articles focused on short-term aesthetic goals, emphasising speedy weight loss without giving up nice foods or exercising. Cluster 3 magazines were associated with post-New Year and 2005 periods. Food advertising was for everyday foods and convenience products, with fewer weight-loss products than other clusters; conversely, article content had a greater prevalence of weight-loss messages.

Conclusions: The cyclical nature of magazine content - indulgence and excess encouraged at Christmas, restraint recommended post-New Year and severe dieting advocated in the summer months - endorses yo-yo dieting behaviour and may not be conducive to public health.
\end{abstract}

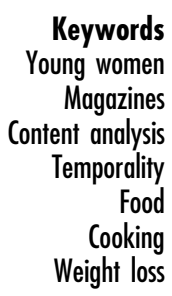

Fashion and beauty magazines have been strongly implicated in fuelling body dissatisfaction and encouraging dieting among teenagers and young women ${ }^{(1-3)}$. Specifically, meta-analytic studies demonstrate that exposure to magazines is associated with disordered eating in both cross-sectional and longitudinal designs ${ }^{(4)}$. Glorification of slenderness is central to magazines' depiction of a beauty ideal ${ }^{(5)}$, with images of thin and glamorous models juxtaposed alongside articles exhorting readers to follow diet and exercise regimes for weight loss. Advertisements for slimming foods may add to this mix.

A limited body of research has systematically examined weight-loss information in print media orientated to young women. Weight loss has been found to be a mainstay of both articles and advertising content in a North American teenage magazine ${ }^{(6)}$, although content devoted to dieting declined between the 1980 s and $2005^{(7)}$. Advertising of weight-loss products has been reported to be seasonal in teenage magazines, with more advertisements in June compared with September issues, but there was no seasonal pattern in magazines for older women ${ }^{(8)}$.

Albeit that young women may have high levels of body dissatisfaction, attainment of body weight ideals may be difficult within prevailing youth culture in which overconsumption of affordable, palatable, energy-dense, processed foods is the norm ${ }^{(9,10)}$. Overweight and obesity rates are at unprecedented levels among young people in many countries; recent data from the Health Survey of England 2009 showed that $40 \%$ of women aged 16 to 34 years were classified as overweight or obese ${ }^{(11)}$. Persuasive food and beverage marketing has been identified as a major driver of the obesity epidemic ${ }^{(9,10)}$, with particular criticism of such marketing to children and 
young people. Food advertising in print media is substantial; in $2007 £ 92.4$ million was spent on food advertising in print media in the UK, accounting for $19 \cdot 1 \%$ of all food advertising ${ }^{(12)}$.

Food and beverage marketing in women's magazines has been analysed by readership demographic and temporality ${ }^{(13-16)}$. These studies showed that food advertising is dominated by convenience foods, foods high in fat and/or refined sugar and alcoholic beverages, with a widespread lack of advertising of fruits and vegetables. This weighting was particularly marked in magazines orientated to young women, with advertising for chocolate and alcohol common $^{(17)}$. A study of British women's monthly magazines of the time period 2008/2009 found that food advertising was more prevalent in magazines with an affluent readership and over the summer months, while alcohol advertising peaked over the Christmas period ${ }^{(15)}$.

Feature articles and editorial copy in print media have also been studied. Madden and Chamberlain explored the construction of food and healthy eating in popular New Zealand women's magazines using discourse analysis ${ }^{(18)}$, while Schneider and Davis unveiled a longstanding discourse of health in a time-series analysis of a mainstream Australian women's magazine ${ }^{(19)}$. In a temporal analysis of British women's magazines, Warde noted that representation of food consumption for health and nutrition reasons increased in the time period 1967 to 1994, while articles dealing explicitly with slimming declined, although energy (calorie counts) and nutrition information became more prevalent ${ }^{(20)}$. Similarly Barker et al. ${ }^{(21)}$ reported greatest visibility of slimming messages in both articles and food advertising in British women's magazines of the 1970s compared with those from earlier and later decades.

The current study examines seasonal and temporal patterns in food advertising and article content in two UK magazines aimed at young women over a 12-year period. This time period witnessed climbing rates of obesity in the UK conflated with the longstanding problem of disordered eating in teenagers and young women. Although true incidence of eating disorders is difficult to estimate, reports indicate that incidence among British children has increased $^{(22)}$, while admission rates for eating disorders to English hospitals increased by some $50 \%$ between 1996 and $2006^{(23)}$.

\section{Methods}

Statistics from the National Readership Survey were used to identify the two most popular women's monthly 'lifestyle' periodicals with a predominantly young (age 15-44 years) readership. These two titles were Cosmopolitan and Glamour, which are both aimed at young, single women without children. Cosmopolitan and Glamour draw similar sized audiences $(1 \cdot 8$ million and $1 \cdot 2$ million monthly, respectively) of a similar socio-economic status (ratio of $\mathrm{ABC} 1$ to $\mathrm{C} 2 \mathrm{DE}=1 \cdot 7$ and $1 \cdot 6$, respectively). However, Glamour draws a younger audience (ratio of readers aged $15-44$ years to those aged $45+$ years $=3.5$ for Cosmopolitan and $7 \cdot 7$ for Glamour).

The magazines were accessed at Cambridge University Library Periodicals Department. All issues of both magazines from April 2009 to May 2011, and all available issues from 2005, were studied. A full listing of issues surveyed can be seen in Table 1. Imbalance in sampling due to missing magazines through the summer months in 2005 (Glamour) and over the winter months (Cosmopolitan) is of limited consequence, as each month was represented. All issues of Cosmopolitan over a 2-year period from April 1999 to May 2001 were sampled. Glamour was first published in April 2001; therefore all issues from April 2001 to March 2002 were used. The sample comprised fifty-five issues of Cosmopolitan and forty-two issues of Glamour. All advertisements and articles relating to food and/or nutrition were included, giving a total of 590 advertisements and 148 articles. An article was defined as one paragraph or greater of text.

A content analysis based on the food coding scheme devised by Barr ${ }^{(24)}$ and used by others ${ }^{(14,25)}$ was conducted; we categorised branded food and beverage advertisements as present or absent $(\mathrm{y} / \mathrm{n})$ in relation to sixty separate food subgroups covering ten broad food groups (Table 2). Weight-loss claims in advertisements were coded as present or absent according to the nine categories of Barr's scheme (Table 3).

Articles were coded separately to advertisements. All articles which referred to food or dieting were identified, including those of only one paragraph. The number of food articles per magazine was recorded. These articles were coded into three groups according to the focus of

Table 1 Magazines sampled by year and month

\begin{tabular}{lll}
\hline Year & Cosmopolitan & Glamour \\
\hline 1999 & Jul, Aug, Sept, Oct, Nov, Dec & Glamour not published until 2001 \\
2000 & Jan, Feb, Mar, Apr, May, Jun, Jul, Aug, Sep, Oct, Nov, Dec & \\
2001 & Jan, Feb, Mar, Apr, May & Apr, May, Jun, July, Aug, Sep, Oct, Nov, Dec \\
2002 & Jan, Feb, Mar, May, Jun, Jul, Aug, Sep & Jan, Feb, Mar \\
2005 & Jun, Jul, Aug, Sep, Oct, Nov, Dec & Jan, Febr, May, Oct, Nov \\
2009 & Jan, Feb, Mar, Apr, May, Jun, Jul, Aug, Sep, Oct, Nov, Dec & Jun, Jul, Aup, Oct, Nov, Dec \\
2010 & Jan, Mar, Apr, May, Jun, Jul, Aug, Sep, Oct, Nov, Dec \\
2011 & Jan, Feb, Mar, Apr, May & Jan, Feb, Mar, Apr, May \\
Total & 55 & 42 \\
\hline
\end{tabular}


Table 2 Broad food groups and subgroups in the advertisement food type coding scheme*

\begin{tabular}{|c|c|c|c|c|c|}
\hline Food group & Milk \& dairy & Protein & Breads \& cereals & Fruits \& vegetables & $\begin{array}{l}\text { Desserts \& foods high in fat } \\
\text { and/or refined sugar }\end{array}$ \\
\hline Food subgroupst & $\begin{array}{l}\text { Yoghurt } \\
\text { Lactose-free dairy products } \\
\text { Milk } \\
\text { Cheese }\end{array}$ & $\begin{array}{l}\text { Sausages } \\
\text { Vegetarian meat alternatives } \\
\text { Cold meats } \\
\text { Poultry } \\
\text { Bacon } \\
\text { Fish }\end{array}$ & $\begin{array}{l}\text { Crackers } \\
\text { Bread } \\
\text { Pasta } \\
\text { Rice } \\
\text { Breakfast } \\
\text { cereals }\end{array}$ & $\begin{array}{l}\text { Mushrooms (EU campaign) } \\
\text { Fruit salad } \\
\text { Baked beans } \\
\text { Tinned fruit } \\
\text { Dried fruit } \\
\text { Fruit juice }\end{array}$ & $\begin{array}{l}\text { Confectionery } \\
\text { Biscuits \& cakes } \\
\text { Soft drinks } \\
\text { Crisps } \\
\text { Pastries } \\
\text { Ice cream } \\
\text { Desserts } \\
\text { Energy drinks }\end{array}$ \\
\hline No. of food subgroups & 4 & 6 & 5 & 6 & 8 \\
\hline Food group & $\begin{array}{l}\text { Condiments, cooking } \\
\text { ingredients and fat spreads }\end{array}$ & $\begin{array}{l}\text { Beverages (other than milk, } \\
\text { juice \& sugared beverages) }\end{array}$ & Convenience foods & Products to lose weight & Miscellaneous \\
\hline Food subgroupst & $\begin{array}{l}\text { Mayonnaise } \\
\text { Salad dressing } \\
\text { Olive oil } \\
\text { Margarine/other spreads } \\
\text { Herbs \& spices } \\
\text { Stock } \\
\text { Cake mix }\end{array}$ & $\begin{array}{l}\text { Fruit, mint or herbal teas } \\
\text { Electrolytic 'light' sports drinks } \\
\text { 'Diet' soft drinks } \\
\text { Alcohol } \\
\text { Tea } \\
\text { Water } \\
\text { Coffee } \\
\text { Hot chocolate }\end{array}$ & $\begin{array}{l}\text { Soup } \\
\text { Pre-packaged snacks } \\
\text { Jarred sauces } \\
\text { Pre-packaged sandwiches } \\
\text { Frozen ready-meals/pizzas } \\
\text { Frozen chips }\end{array}$ & $\begin{array}{l}\text { Weight-loss plans/services } \\
\text { Special Kt } \\
\text { Ready meals } \\
\text { Snacks } \\
\text { Desserts } \\
\text { Meal replacements } \\
\text { Weight-loss pills }\end{array}$ & $\begin{array}{l}\text { Supplements } \\
\text { Soya products } \\
\text { Sweeteners }\end{array}$ \\
\hline No. of food subgroups & 7 & 8 & 6 & 7 & 3 \\
\hline
\end{tabular}

All magazines were coded for whether each subgroup was present or absent Adapted from Barr ${ }^{(24)}$

tAlso coded under meal replacements. 
Table 3 Coding used for weight-loss messages ${ }^{*}$

\begin{tabular}{ll}
\hline Claim type & Specific claims \\
\hline Weight loss & Losing weight will make you look good \\
& Losing weight will make you feel better about \\
yourself & Addressing diet \& exercise \\
& Addressing only diet \\
& You can still eat nice food \\
& Tailored to you \\
& Losing weight for health reasons \\
& Success story \\
& Losing weight is easy/great results can be \\
& achieved quickly
\end{tabular}

This scheme was used for articles and advertisements.

${ }^{*}$ Adapted from Barr ${ }^{(24)}$

the article: (i) consumer/nutrition/health; (ii) weight loss; and (iii) cooking (see Table 4). Articles having consumer/ nutrition/health messages were coded as present or absent $(y / n)$ according to the following categories: eating organically; eating for beauty; ethical eating; vegetarianism; how to eat more healthily; eating to improve sleep, stress, premenstrual tension, hangovers, etc; eating for energy; detox advice; drink less alcohol; pro-supplements; eat more iron; food allergies/intolerances; how to put on weight. All these except how to eat more healthily had fewer than ten occurrences and were not analysed further.

Articles discussing weight loss were differentiated into nine categories $(\mathrm{y} / \mathrm{n})$ again according to Barr's coding scheme for weight-loss messages in advertisements (see Table 4).

Articles focusing on cooking were coded according to whether the article contained a recipe $(\mathrm{y} / \mathrm{n})$ with further differentiation as to the type of recipe: $\operatorname{soup}(\mathrm{y} / \mathrm{n})$; easy/ quick main meals $(\mathrm{y} / \mathrm{n})$; cakes/desserts $(\mathrm{y} / \mathrm{n})$; cocktails $(\mathrm{y} / \mathrm{n})$; salads $(\mathrm{y} / \mathrm{n}) ;$ party food/savoury snacks $(\mathrm{y} / \mathrm{n})$; healthy recipes/healthier versions $(y / n)$; luxury meals, special occasions, cooking to impress $(\mathrm{y} / \mathrm{n})$.

Microsoft Office Excel 2007 was used for coding of advertisements and articles. A second author coded a 10\% sample of magazines independently. For advertisements there was $91.1 \%$ agreement in coding $(\kappa=0 \cdot 466, P<0 \cdot 001)$, and articles had $87.5 \%$ agreement $(\kappa=0.550, P<0.001)$.

Coding data were imported into the statistical software package IBM SPSS Statistics $19 \cdot 0$ for statistical analysis. For each magazine, the presence or absence of food advertising at the level of sixty food subgroups and the presence or absence of advertising of the nine weight-loss claims was recorded. Similarly, the number of articles was recorded and article focus was coded as absent/present by issue.

Hierarchical cluster analysis was performed on the presence of food advertisements (sixty food subgroups) using pattern measure and within-cluster amalgormation ${ }^{(26)}$; the dendogram indicated three distinct magazine groups. Then $\chi^{2}$ analyses were used to explore if these three magazine clusters of food type advertising were related to: (i) month
Table 4 Coding scheme for articles for consumer/nutrition/health content, weight-loss content and cooking content

\begin{tabular}{cl}
\hline $\begin{array}{c}\text { Consumer/ } \\
\text { nutritional/health }\end{array}$ & How to eat more healthily \\
& Eating for beauty \\
& Eating to improve sleep, stress, \\
premenstrual tension, hangovers, etc. \\
Eating for energy \\
Eating organically \\
Detox \\
Drink less alcohol \\
Pro-supplements \\
Eat more iron \\
Ethical eating \\
Vegetarianism \\
Food allergies/intolerances \\
How to put on weight \\
Addressing diet \& exercise \\
Losing weight to improve health \\
Losing weight won't be easy \\
Losing weight to be more attractive \\
Success story \\
Comparison to celebrities \\
Tailored to you \\
Losing weight is easy/quick \\
Soup \\
Easy/quick main meals \\
Cakes/desserts \\
Cocktails \\
Salads \\
Party food/savoury snacks \\
Healthy recipes/healthier versions \\
Luxury meals, special occasions, cooking to \\
impress \\
Cooking &
\end{tabular}

*Adapted from Barr ${ }^{(24)}$.

and year of publication; (ii) weight-loss messages in advertisements; (iii) number of articles; (iv) weight-loss message in articles; and (v) presence of recipe, dish type and style of cooking. The probabilities quoted are exact probabilities as some of the cells had expected values of less than five.

\section{Results}

The three magazine clusters, designated clusters 1, 2 and 3, are shown in Table 5 according to their advertising of food types. A total of $46 \cdot 4 \%(n 45)$ of sampled magazines comprised cluster $1,37 \cdot 1 \%$ ( $n$ 36) magazines comprised cluster 2 and $16.5 \%$ ( $n$ 16) magazines comprised cluster 3 .

The frequency of advertising of these food types within the data set of all magazines is also shown in Table 5. Advertisements for alcohol, jarred sauces, weight-loss plans/services, Special K, weight-loss meal replacements and yoghurt were most prevalent.

Clusters were associated with month and year of publication (Table 6). Cluster 1 was most likely to feature in a pre-Christmas period, cluster 2 in a summer period and cluster 3 in a post-Christmas period (it should be noted that magazines are on sale, and therefore read, the month preceding their date). Cluster 1 was most likely to feature in the earliest time period sampled, 1999-2001; 
cluster 2 in the most recent period, 2010; and cluster 3 at the mid-point, 2005.

Magazine clusters were associated with advertising weight-loss claims (Table 7). Advertisements in cluster 2 magazines were most likely to contain weight-loss

Table 5 Food type advertising in each cluster of magazines by frequency of occurrence across all magazines and as a percentage of total magazines: content analysis of two British young women's magazines from three time blocks between 1999 and 2011

\begin{tabular}{lcc}
\hline & $\begin{array}{c}\text { No. of } \\
\text { occurrences }\end{array}$ & $\begin{array}{c}\% \text { of } \\
\text { magazines }\end{array}$ \\
\hline Foods in cluster 1 & & \\
Cheese & 16 & $16 \cdot 5$ \\
Vegetarian meat alternatives & 5 & $5 \cdot 2$ \\
Alcohol & 47 & $48 \cdot 5$ \\
Coffee & 18 & $18 \cdot 6$ \\
Jarred sauces & 25 & $25 \cdot 8$ \\
Weight-loss pills & 7 & $7 \cdot 2$ \\
Foods in cluster 2 & & \\
Soft drinks (sugared) & 14 & $14 \cdot 4$ \\
Weight loss plans/services & 32 & $33 \cdot 0$ \\
Special K & 27 & $27 \cdot 8$ \\
Weight-loss meal & 31 & $32 \cdot 0$ \\
replacements & & \\
Foods in cluster 3 & & \\
Yoghurt & 20 & $20 \cdot 6$ \\
Cold meats & 2 & $2 \cdot 1$ \\
Bread & 5 & $5 \cdot 2$ \\
Breakfast cereal & 14 & $14 \cdot 4$ \\
Soup & 6 & $6 \cdot 2$ \\
Weight-loss snacks & 17 & $17 \cdot 5$ \\
Weight-loss desserts & 11 & $11 \cdot 3$ \\
Soya products & 6 & $6 \cdot 2$ \\
\hline
\end{tabular}

Table 6 Associations between magazine food type clusters and month and year of publication: content analysis of two British young women's magazines from three time blocks between 1999 and 2011

\begin{tabular}{lll}
\hline Cluster 1 & Cluster 2 & Cluster 3 \\
\hline $\begin{array}{l}\text { Month* } \\
\text { January }\end{array}$ & May & February \\
$\begin{array}{l}\text { November } \\
\text { December }\end{array}$ & August & March \\
$\begin{array}{l}\text { Yeart } \\
1999-2001\end{array}$ & 2010 & \\
\hline
\end{tabular}

${ }^{*} \chi^{2}=36 \cdot 33, \mathrm{df}=22, P<0.001$.

$t^{2}$
$\chi^{2}$ messages and those in cluster 1 magazines were least likely. Advertisements suggesting that weight loss should be achieved for health reasons were minimal; although to the extent that they were present, they were most apparent in cluster 1 magazines. Cluster 2 magazines had the greatest proportion of advertising advocating weight loss as a means to look good and increase self-esteem. Advertisements advising that losing weight is easy and/or that great results can be achieved quickly without having to give up eating nice foods, and advising diet change without including exercise, were most likely in cluster 2 magazines.

Magazine clusters were also associated with number of articles, article subject, weight-loss messages in articles and recipe type (Table 8 ). Cluster 1 magazines were most likely to have one article, while cluster 2 and 3 magazines were most likely to have two articles. A high proportion of all articles across all clusters were based on recipes; cluster 1 magazines were most likely to include a recipe within an article and cluster 3 magazines least likely. The recipes in cluster 1 magazines were most likely to be for cakes/desserts, while luxury meals/cooking for special occasions or to impress, and party food/savoury snacks were also strongly represented. These types of recipes were much less represented in cluster 3 magazines. There was no significant difference in other recipe types across clusters. In general weight loss was not a major focus of article content in any cluster, although weight-loss articles were most prevalent in cluster 3, with content tending to weight-loss success of ordinary readers and comparisons to celebrities.

\section{Discussion}

\section{Cluster 1: party time}

This cluster was temporally associated with Christmas, New Year and Millennium holiday periods and magazines published between 1999 and 2002. The profile of food advertising was consistent with Christmas food consumption patterns, i.e. cheese, coffee and alcohol ${ }^{(27)}$, and in line with seasonal changes in level of alcohol advertising in British women's magazines ${ }^{(15)}$. Greater regulation of alcohol advertising in magazines published after $2005^{(28)}$ may have

Table 7 Magazine food type clusters by weight-loss messages in advertisements (total number of magazines advertising the message and percentage of magazines in the cluster): content analysis of two British young women's magazines from three time blocks between 1999 and 2011

\begin{tabular}{|c|c|c|c|c|c|c|c|c|c|}
\hline & \multicolumn{2}{|c|}{ Cluster 1} & \multicolumn{2}{|c|}{ Cluster 2} & \multicolumn{2}{|c|}{ Cluster 3} & \multirow[b]{2}{*}{$\chi^{2}$} & \multirow[b]{2}{*}{ df } & \multirow[b]{2}{*}{$P$} \\
\hline & $n$ & $\%$ & $n$ & $\%$ & $n$ & $\%$ & & & \\
\hline Losing weight for health reasons & 6 & $13 \cdot 3$ & 1 & $2 \cdot 8$ & 0 & $0 \cdot 0$ & $4 \cdot 82$ & 2 & 0.036 \\
\hline Losing weight will make you look good & 6 & $13 \cdot 3$ & 17 & $47 \cdot 2$ & 4 & $25 \cdot 0$ & $11 \cdot 51$ & 2 & $<0.001$ \\
\hline Losing weight will make you feel better about yourself & 4 & 8.9 & 15 & $41 \cdot 7$ & 2 & $12 \cdot 5$ & $13 \cdot 61$ & 2 & $<0.001$ \\
\hline Addressing only diet & 6 & $13 \cdot 3$ & 13 & $36 \cdot 1$ & 2 & $12 \cdot 5$ & $7 \cdot 06$ & 2 & 0.008 \\
\hline You can still eat nice food & 1 & $2 \cdot 2$ & 13 & $36 \cdot 1$ & 4 & $25 \cdot 0$ & $15 \cdot 72$ & 2 & $<0.001$ \\
\hline Losing weight is easy/great results can be achieved quickly & 8 & $17 \cdot 8$ & 19 & $52 \cdot 8$ & 5 & $31 \cdot 3$ & $11 \cdot 11$ & 2 & $<0.001$ \\
\hline
\end{tabular}


Table 8 Magazine food type cluster in relation to number of articles and article content (total number of magazines and percentage of magazines in the cluster): content analysis of two British young women's magazines from three time blocks between 1999 and 2011

\begin{tabular}{|c|c|c|c|c|c|c|c|c|c|}
\hline & \multicolumn{2}{|c|}{ Cluster 1} & \multicolumn{2}{|c|}{ Cluster 2} & \multicolumn{2}{|c|}{ Cluster 3} & \multirow[b]{2}{*}{$x^{2}$} & \multirow[b]{2}{*}{ df } & \multirow[b]{2}{*}{$P$} \\
\hline & $n$ & $\%$ & $n$ & $\%$ & $n$ & $\%$ & & & \\
\hline One article & 31 & 68.9 & 14 & $38 \cdot 9$ & 5 & $31 \cdot 3$ & $11 \cdot 13$ & 4 & 0.008 \\
\hline Two articles & 12 & $26 \cdot 7$ & 20 & $55 \cdot 6$ & 9 & $56 \cdot 3$ & & & \\
\hline Weight loss - success story & 4 & 8.9 & 3 & $8 \cdot 3$ & 4 & $25 \cdot 0$ & $3 \cdot 56$ & 2 & 0.036 \\
\hline Weight loss - comparison to celebrities & 3 & $6 \cdot 7$ & 1 & $2 \cdot 8$ & 4 & $25 \cdot 0$ & $7 \cdot 51$ & 2 & 0.009 \\
\hline Recipes article & 34 & $75 \cdot 6$ & 23 & 63.9 & 7 & $43 \cdot 8$ & $5 \cdot 43$ & 2 & 0.021 \\
\hline Recipes - cakes/desserts & 18 & $40 \cdot 0$ & 10 & $27 \cdot 8$ & 1 & $6 \cdot 3$ & $6 \cdot 54$ & 2 & 0.007 \\
\hline Recipes - luxury meals, special occasions, cooking to impress & 11 & $24 \cdot 4$ & 2 & $5 \cdot 6$ & 3 & $18 \cdot 8$ & $5 \cdot 25$ & 2 & 0.028 \\
\hline Recipes - party food/savoury snacks & 8 & $17 \cdot 8$ & 7 & $19 \cdot 4$ & 0 & $0 \cdot 0$ & 3.55 & 2 & 0.081 \\
\hline
\end{tabular}

contributed to the effect. Furthermore, inclusion of magazines published over the Millennium period will have reinforced festive patterns.

Young women are known users of convenience foods ${ }^{(29)}$, which fits with the presence of advertising for jarred sauces in the cluster. Vegetarian women outnumber men in many Western societies and vegetarianism is particularly popular among young women, possibly as a means to restrain eating ${ }^{(30-33)}$. Advertisements for vegetarian meat alternatives in cluster 1 magazines may reflect seasonal demand as part of vegetarian Christmas dining.

There was a strong presence of recipes in article content, which is congruent with the role of cooking, eating with the family and sharing of food as germane to Christmas celebrations ${ }^{(18,27)}$. The type of recipes recommended represented unfettered, hedonistic consumption, with recipes focusing on cakes/desserts, luxury meals/ food to impress others/food for special occasions, and party food/savoury snacks; indulgence, enjoyment and celebration through food were represented large. Warde's analysis of food column content in British magazines of the early 1990s unveiled an antinomy of health $v$. indulgence in magazine article content - strictures to lose weight, eat healthily and show self-discipline for the sake of a slim and attractive body sat cheek by jowl with advocacy to seek solace with comfort food, break diet rules and indulge food cravings ${ }^{(20)}$.

This cluster of magazines largely avoided such dichotomy; even weight-loss advertising solely comprised quick-fix pills for pain-free weight loss without sacrifice or the self-discipline of dietary restriction. However, advertising messages addressing losing weight for health reasons (as opposed to cosmetic reasons) did feature minimally $(13 \cdot 3 \%)$. Other research, albeit now dated, noted that health and nutrition advice was minimal in British teenage magazines $^{(34)}$ and similarly in Australian teenage magazines ${ }^{(17)}$. This contrasts with a longstanding and strong health and nutrition discourse in advertising messages in Australian lifestyle magazines for mature women ${ }^{(19)}$.

\section{Cluster 2: bikini body}

This group of magazines was associated with spring and summer months of May and August and with the time period 2010. Weight-loss food products in conjunction with weight-loss plans dominated advertising in the cluster, with everyday foods absent aside from soft sugary drinks. The overwhelming weight-loss messages within advertising was that weight loss would result in improvements in appearance, and that weight loss was easy to achieve without exercise or restricting nice food. Construction and honing of a bikini body for summer was a main end. This seasonally based emphasis on weight loss for cosmetic ends corroborates studies of both advertising and article content of North American teenage magazines ${ }^{(6,8)}$. Low representation of advertising of core foods has also been noted in Australian young women's magazines ${ }^{(17)}$.

Young women were therefore encouraged to purchase specially formulated foods and follow diet plans not for reasons of health, but by a proverbial carrot of improvements in appearance. Magazines have long been blamed for spearheading social pressure for women to diet; more specifically they have been implicated in encouraging teenagers and young women to veer to restrained consumption and disordered eating ${ }^{(1-3)}$. A svelte body is fundamental to magazines' subscribed beauty ideal, with youth, femininity, happiness, success and attractiveness equated to slimness, while failure to meet this ideal is stigmatised ${ }^{(35-37)}$. Weight-loss messages in this cluster were also heavily weighted towards improvement in self-esteem. Somewhat paradoxically, body dissatisfaction has been shown to be the norm for young women ${ }^{(38-40)}$. This phenomenon was wonderfully demonstrated in a sociological study of women from North East England, which reported that many women believed they would be happier and more confident if they were half a stone lighter ${ }^{(36)}$.

The suggested recipes within articles in cluster 2 magazines counterpoised weight-loss messages. These tended to be for cakes and desserts, party foods and savoury snacks, which are associated with pleasure and, with their high content of fat and sugar, opposite to weight-reducing food messages. This contrast is congruent with an antinomy of health $v$. indulgence apparent in the food columns of British women's magazines ${ }^{(41)}$.

Women's sartorial appearance is linked to economic cycles $^{(42)}$, thus the focus on body image and looking 
good in cluster 2 magazines may related to the economic downturn of 2008. Similarly, the strong presence of recipes for cakes and desserts, but fewer for luxury meals may reflect gravitation to more economical home cooking $^{(43)}$. Hard times also bring about a return to traditional or comfort foods such as cakes and desserts, as people are pulled to the reassuring and familiar in times of uncertainty, rather than food to impress ${ }^{(44)}$. Modern women, balancing domestic demands with professional life, seek comfort in the familiarity of food 'how mother made it' and indeed since the Millennium there has been a renaissance in home baking within British cook books, with strong connotations of comfort and reassurance ${ }^{(45)}$.

\section{Cluster 3: going steady}

The third food type cluster was reflective of a steady and everyday approach to eating. Cluster 3 comprised magazines advertising foods of the everyday such as yoghurt, cold meats, bread, breakfast cereals, soups and soya products. The cluster also featured weight-loss products in the form of snacks and desserts. Cluster 3 was associated with post-New Year and 2005 time periods.

Such 'grab and go' foods, such as soups, breakfast cereals and yoghurt, are particularly relevant for the magazines' target audience, considering that young people who have recently left home often have limited cooking skills and rely on takeaways and convenience foods ${ }^{(46,47)}$. To boot, convenience food advertising has been shown to be prominent across a broad spectrum of British magazines ${ }^{(15,16)}$. Advertising of weight-loss products also addressed convenience, since instant snacks and desserts designed for slimming were especially visible in this cluster. Such advertising of slimming snacks and desserts married contradictory notions of indulgence and restriction, allowing the dieter a 'treat' food, a 'bad' food and a slimming food in one fell swoop; representation of food as being naughty and bad, but being used as a reward for weight loss, has been previously noted in the context of advice outpouring from commercial slimming organisations ${ }^{(48)}$.

The year 2005 was a time of economic stability, when employment and financial factors in people's lives were generally stable. It was not a year of particular economic boom, but nor was the UK in economic recession, and everyday eating, as evidenced in cluster 3 advertisements, mirrors that steady and assured period. Advertised foods tended to be dietary staples and may reflect advertising congruent with non-holiday periods founded on prosaic, everyday eating routines. There were fewer recipes in cluster 3 magazines, especially for cakes and desserts and party foods, probably due to this seasonal effect.

Generally cluster 3 had less weight-loss advertising than the bikini body cluster. The temporal position of this cluster may have a bearing on this scarcity, in that following the excesses of Christmas, households may reduce their food spend ${ }^{(49)}$ and therefore there is a reduced market for premium weight-loss products. Furthermore in stable time periods advertising that promises a quick-fix solution may be viewed sceptically, while self-denial may be seen more positively. Greater prevalence of food and nutrition articles supports the behaviour-changing emphasis of the cluster and is in keeping with a postNew Year interest in healthy eating and sustained weight loss. In contrast to the individualised nature of weightloss messages in advertisements, messages in articles socialised the reader as a member of a weight-loss community; thus weight loss was often discussed in the context of success stories of other readers, or celebrity dieting stories.

\section{Overview}

The magazine content analysed in the current study supports known eating habits of young women: vegetarianism, convenience eating and dieting ${ }^{(5,29,30,33)}$. Weight-loss messages were systemic across clusters, and these focused on short-term aesthetic goals rather than longterm health benefits. Advertising and articles represented losing weight as a quick and easy process, fostering an ideal contrary to the majority of dieters' experience ${ }^{(50)}$.

While we have unveiled seasonal and temporal clusters embracing both magazine article content and advertisement content in two popular young women's magazines, interpretation of these results must be tempered in that we scrutinised only two magazines. Although Cosmopolitan and Glamour are popular magazines for young women in the UK, they are unlikely to be representative of all young women's magazines. Moreover our temporal analyses are founded on a relatively small number of issues.

Nevertheless, seasonal variations in food and weightloss messages were particularly strong: excessive eating prevailed in the run-up to Christmas, healthy eating and a more prosaic food pattern was advocated in the months following New Year, while dieting was dominant in the summer. This pattern of excessive consumption punctuated by periods of restriction is nutritionally unsound and is associated with poor psychological and health outcomes ${ }^{(51)}$. There is an established axis between body dissatisfaction, binge eating and dietary restraint ${ }^{(52,53)}$. Weight cycling or yo-yo dieting is not conducive to successful long-term weight loss; Lowe et al. ${ }^{(54)}$ reported that a history of unsuccessful dieting independently predicted weight gain in young women during their first year of college, noting that there was some evidence that unsuccessful dieting is associated with appetite deregulation, increases in metabolic efficiency and disordered eating. Our observation of seasonal advocacy of consumption followed by restriction, which synchronised across both media of advertisements and articles, seems likely to propagate body dissatisfaction and encourage yo-yo dieting. Furthermore, longer-term temporal influences may exacerbate these patterns. 
Such emphasis on quick-fix crash dieting is tragic given that women's magazines have great potential to disseminate public health messages about diet. The complex and contradictory nature of cooking, weight-loss and consumption messages observed in the present study highlights the need for further scrutiny of food and dieting content of print media aimed at young women.

\section{Acknowledgements}

Sources offunding: This study was carried out as part of a Master's degree programme at the University of Sheffield. The University of Sheffield covered its running costs, but had no role in the design and analysis of the study or the writing of this manuscript. Conflicts of interest: No author has a personal or financial conflict of interest. Ethics: Ethical approval was not required. Authors' contributions: M.E.B. conceived and designed the study; R.J.S. drew up the sample of magazines and carried out coding for the content analysis; J.M.R. carried out the statistical analysis. R.J.S. wrote the first draft of the manuscript. M.E.B. redrafted the manuscript aided by J.M.R. All authors approved the final manuscript.

\section{References}

1. López-Guimerà G, Levine MP, Sánchez-Carracedo D et al. (2010) Influence of mass media on body image and eating disordered attitudes and behaviors in females: a review of effects and processes. Media Psychol 13, 387-416.

2. Mooney E, Farley H \& Strugnell C (2009) A qualitative investigation into the opinions of adolescent females regarding their body image concerns and dieting practices in the Republic of Ireland (ROI). Appetite 52, 485-491.

3. Van den Berg P, Neumark-Sztainer D, Hannan PJ et al. (2007) Is dieting advice from magazines helpful or harmful? Five-year associations with weight-control behaviors and psychological outcomes in adolescents. Pediatrics 119, e30-e37.

4. Levine MP \& Murnen SK (2009) 'Everybody knows that Mass Media are/are not [pick one] a cause of eating disorders': a critical review of evidence for a causal link between media, negative body image, and disordered eating in females. Body Image 28, 9-42.

5. Hill AJ (2007) Symposium on 'Nutrition and health in children and adolescents' Session 3: eating behaviour and early indicators of metabolic syndrome motivation for eating behaviour in adolescent girls: the body beautiful. Proc Nutr Soc 65, 376-384.

6. Guillen EO \& Barr SI (1994) Nutrition, dieting, and fitness messages in a magazine for adolescent women, 1970-1990. $J$ Adolesc Health 15, 464-472.

7. Luff GM \& Gray JJ (2009) Complex messages regarding a thin ideal appearing in teenage girls' magazines from 1956 to 2005. Body Image 6, 133-136.

8. Korinis M, Korslund MK, Belli G et al. (1998) Comparison of calcium and weight loss information in teen-focused versus women's magazines over two 4-year periods (1986-1989 and 1991-1994). J Nutr Educ 30, 149-154.

9. Fitzgibbon ML \& Stolley M (2006) Promoting health in an unhealthful environment: lifestyle challenges for children and adolescents. J Am Diet Assoc 106, 518-522.
10. Swinburn BA, Sacks G, Hall KD et al. (2011) The global obesity pandemic: shaped by global drivers and local environments. Lancet 378, 804-814.

11. Aresu M, Chaudhury M, Diment E et al. (2010) Health Survey for England 2009. vol. 1: Health and Lifestyles. London: The NHS Information Centre Centre for Health and Social Care.

12. Office of Communications (2007) HFSS Advertising Restrictions - Experience to Date and Next Steps. London: Ofcom.

13. Duerksen SC, Mikail A, Tom L et al. (2005) Health disparities and advertising content of women's magazines: a cross-sectional study. BMC Public Health 5, 85.

14. Lohmann J \& Kant AK (2000) comparison of food groups and health claims appearing in food advertisements in 3 popular magazine categories. J Am Diet Assoc 100, 1396-1399.

15. Adams J, Simpson E \& White M (2011) Variations in food and drink advertising in UK monthly women's magazines according to season, magazine type and socio-economic profile of readers: a descriptive study of publications over 12 months. BMC Public Health 11, 368.

16. Adams J \& White M (2009) Socio-economic and gender differences in nutritional content of foods advertised in popular UK weekly magazines. Eur J Public Health 19, 144-149.

17. Hill JM \& Radimer K (1996) Health and nutrition messages in food advertisements: a comparative content analysis of young and mature Australian women's magazines. J Nutr Educ 28, 313-320.

18. Madden H \& Chamberlain K (2004) Nutritional health messages in women's magazines: a conflicted space for women readers. J Health Psychol 9, 583-597.

19. Schneider T \& Davis T (2010) Fostering a hunger for health: food and the self in 'The Australian Women's Weekly'. Health Sociol Rev 19, 285-303.

20. Warde A (1997) Consumption, Food and Taste. London: SAGE Publications.

21. Barker ME, McNeir K, Sameer S et al. (2013) Food, nutrition and slimming messages in British women's magazines, 1950-1998. J Hum Nutr Diet (Epublication ahead of print version).

22. Nicholls DE, Lynn R \& Viner RM (2011) Childhood eating disorders: British national surveillance study. Br J Psychiatry 198, 295-301.

23. Disordered Eating (2012) Eating Disorders Statistics (UK). http://www.disordered-eating.co.uk/eating-disordersstatistics/eating-disorders-statistics-uk.html (accessed March 2012).

24. Barr SI (1989) Nutrition in food advertising: content analysis of a Canadian women's magazine. J Nutr Educ 21, 64-72.

25. Pratt CA \& Pratt CB (1996) Nutrition advertisements in consumer magazines: health implications for African Americans. J Black Stud 26, 504-523.

26. Norusis M \& SPSS Inc. (2010) PASW Statistics 18: Statistical Procedures Companion. Upper Saddle River, NJ: Pearson.

27. Pitts M, Pattie C \& Dorling D (2007) Christmas feasting and social class: Christmas feasting and everyday consumption. Food, Culture Soc 10, 407-424.

28. Advertising Standards Authority (2009) Alcohol Advertising Survey 2009. http://www.asa.org.uk/News-resources/ / media/Files/ASA/Reports/Alcohol\%20Advertising\%20Survey\% 202009.ashx (accessed September 2011).

29. Buckley M, Cowan C \& McCarthy M (2007) The convenience food market in Great Britain: convenience food lifestyle (CFL) segments. Appetite 49, 600-617.

30. Kenyon PM \& Barker ME (1998) Attitudes towards meateating in vegetarian and non-vegetarian teenage girls in England - an ethnographic approach. Appetite 30, 185-198. 
31. Kubberød E, Ueland $\varnothing$, Rødbotten M et al. (2002) Gender specific preferences and attitudes towards meat. Food Qual Prefer 13, 285-294.

32. Ruby MB (2012) Vegetarianism. A blossoming field of study. Appetite 58, 141-150.

33. Forestell CA, Spaeth AM \& Kane SA (2012) To eat or not to eat red meat. A closer look at the relationship between restrained eating and vegetarianism in college females. Appetite 58, 319-325.

34. Davies E (1986) An examination of health education in teenage magazines. Health Educ J 45, 86-91.

35. Germov J \& Williams L (1996) The epidemic of dieting women: the need for a sociological approach to food and nutrition. Appetite 27, 97-108.

36. Charles N \& Kerr M (1986) Food for feminist thought. Sociol Rev 34, 537-572.

37. Orbach S (1993) Hunger Strike: The Anorectic's Struggle as a Metaphor for Our Age. London: Penguin.

38. Hill AJ, Oliver S \& Rogers PJ (1992) Eating in the adult world: the rise of dieting in childhood and adolescence. Br J Clin Psychol 31, 95-105.

39. Field AE, Cheung L, Wolf AM et al. (1999) Exposure to the mass media and weight concerns among girls. Pediatrics 103, e36.

40. Wardle J, Haase AM \& Steptoe A (2006) Body image and weight control in young adults: international comparisons in university students from 22 countries. Int J Obes (Lond) 30, 644-651.

41. Warde A (1994) Changing vocabularies of taste, 1967-92: discourses about food preparation. Br Food J 96, 22-25.

42. Van Baardwijk M \& Franses P (2010) The Hemline and The Economy: Is There Any Match? Econometric Institute Report no. EI 2010-40. Rotterdam: Erasmus University, Econometric Institute.
43. Mintel Group Ltd (2010) Impact of the Recession on Eating Out Habits - UK - October 2010. London: Mintel.

44. Johnston J \& Baumann S (2010) Foodies: Democracy and Distinction in the Gourmet Foodscape. Abingdon: Taylor \& Francis.

45. Humble N (2005) Culinary Pleasures: Cookbooks and the Transformation of British Food. London: Faber and Faber.

46. Lang T, Caraher M, Dixon P et al. (1999) Cookery Skills and Health. London: Health Education Authority.

47. Brunner TA, Van der Horst K \& Siegrist M (2010) Convenience food products. Drivers for consumption. Appetite 55, 498-506.

48. Mycroft H (2008) Morality and accountability in a commercial weight management group. J Health Psychol 13, 1040-1050.

49. Cai LA (1998) Analyzing household food expenditure patterns on trips and vacations: a Tobit model. J Hospitality Tourism Res 22, 338-358.

50. Green AR, Larkin M \& Sullivan V (2009) Oh stuff it! The experience and explanation of diet failure: an exploration using interpretative phenomenological analysis. $J$ Health Psychol 14, 997-1008.

51. Brownell KD \& Rodin J (1994) Medical, metabolic, and psychological effects of weight cycling. Arch Intern Med 154, 1325-1330.

52. Wardle J, Waller J \& Rapoport L (2001) Body dissatisfaction and binge eating in obese women: the role of restraint and depression. Obes Res 9, 778-787.

53. Ricciardelli L, Tate D \& Williams RJ (1997) Body dissatisfaction as a mediator of the relationship between dietary restraint and bulimic eating patterns. Appetite 29, 43-54.

54. Lowe MR, Annunziato RA, Markowitz JT et al. (2006) Multiple types of dieting prospectively predict weight gain during the freshman year of college. Appetite 47, 83-90. 